\title{
Panglima Laot: His Legacy and Role in Conserving Marine Resources in Aceh, Indonesia
}

\author{
Muhammad Adli Abdullah ${ }^{1}$ Azmi Arifin $^{2}$ and Sulaiman Tripa $^{3}$ \\ ${ }^{1}$ Syiah Kuala University, Adat Department, 23111 Banda Aceh, Indonesia \\ ${ }^{2}$ Universiti Sains Malaysia, History Section School of Humanities, 11800 Penang, Malaysia \\ ${ }^{2}$ Syiah Kuala University, Law and Society Department, 23111 Banda Aceh, Indonesia
}

\begin{abstract}
This paper discusses the significance of a historical heritage and its practices based on local wisdom to develop sustainable marine resources in Aceh. Local wisdom can be translated through the examination of the significant role played by the Panglima Laot (Sea Commander) as the enforcer of the Customary Law of the sea in Aceh. This law exists since the glorious era of the Kingdom of Aceh from the 17th century. The role played by the Panglima Laot underlines local wisdom in managing and ensuring the sustainability of the seas, an important economic source for the coastal community in Aceh. The sea is the lifeblood of the Acehnese coastal communities. From a historical point of view, Panglima Laot played a major role in safeguarding and nurturing the sea for the benefits of marine activities and maintaining the marine environment and its natural state, as a common property that should not be destroyed for the good of the future. Panglima Laot also managed marine resources that can be exploited and empowers the population to undertake marine activities in accordance with the customary requirements and the interests of society as a whole. In ensuring the effectiveness of the functions, the role of Panglima Laot is strengthened by the existence of special rules concerning marine and fishing practices established for generations through Adat Laot (Aceh Customary of the sea) to ensure the longterm harmony and sustainability of Aceh's marine resources.
\end{abstract}

\section{Introduction}

This paper aims to explore the legacy and the role of Panglima Laot in preserving the marine resources in Aceh. This paper is significant because Panglima Laot is a traditional Aceh fishery institution that is a legacy of the Aceh civilisation in the past, that but remains alive and continue to evolve to this day. Panglima Laot's role is to enforce the Customary Law of the sea in Aceh which signifies the wealth of local wisdom; it remains contextual for the sustained development of fish resources in Aceh.

Beginning with this interest in mind, the discussion of the existence of Panglima Laot in Aceh cannot be separated from a number of aspects, namely history, anthropology, and law. History will describe the journey of the Panglima Laot's existence from the 17th century or earlier through to the colonial period and up to the present day. Anthropologically, it will illustrate how the progress of every scene in the journey involving Panglima Laot and how they play a role in sustainable marine development. From a legal aspect, it will trace how the Indonesian Kingdom recognises the existence of the Aceh Customary Law of the sea which is based on local wisdom, operating within the Indonesian national legal system which was based on the European Continental system.

The embodiment of Panglima Laot must be seen from a number of aspects since all these aspects define its existence to this date. Up till now, the empirical manifestations can be traced from the dynamics of its development from time to time [12]. Over a span of time, the development can be found to either strengthened or weakened. It is similar to the condition of the country in tandem with the developments in politics and law [15].

There are at least two important dynamics that occurred in the current Aceh socio-politics regarding Panglima Laot: 
First, by placing Panglima Laot as a legacy of the traditional institutions of the Kingdom of Aceh heritage who solely functions in the celebration of adat (customary law) coastal communities. In this context, besides Panglima Laot, there are also a number of other customary institutions at the desa (village) and mukim (village federated) such as Keujruen Blang (Institution of agriculture Custom), Pawang Uteun (Institution of Forestry Custom), Haria Peukan (Institution of traditional market Custom). Imum Mukim (head of village federated). The embodiment of customary institutions is only focused on the concept of maintaining human balance in the community life in Aceh.

Second, ecological implications, where customary institutions become an important part of maintaining the ecology of the coastal and marine spaces in Aceh. In the coastal communities of Aceh, each marine customary territory has its own customary ecological space, which until now has not received full legal recognition.

The embodiment of Panglima Laot is related to the preservation of marine resources in Aceh, so it is impossible to ignore this ecological aspect. The necessity of maintaining ecological aspect in anthropologically explained through the concept of ulayat laot (tenure right of the sea). In the study of anthropology, the discussion on the ulayat laot started in the 1970s $[9,20,18]$. The concept of marine ownership, Indonesia subject to Dutch legal system which bound by the Mare Liberium's teachings that the sea should not be owned by anyone [11]. Mare Liberium's teachings were developed in the 17th century in the Netherlands. While England, Spain and Portugal embraced the Mare Clausum, which states that the sea can be owned. Both of these teachings (Mare Liberium and Mare Clausum) are essentially the same as the theory of res nullius (mare clausum) and res communis (mare liberium).

Although the state did not fully recognise the ulayat Laot rights of the sea, the Aceh coastal community continue to practice it as the legacy of the Kingdom of Aceh. In this case, Adhuri states that the practice of ulayat Laot rights or the management of traditional marine resources continues to be applied in Indonesia as an alternative maintenance practice [9].

The adat management needs to be brought closer to the community in order to maintain the adat ecological space. The existence of Adat ecological space determined by how the government's policy administered [14]. Furthermore, ecological space allows this type of local wisdom to be used in the context of marine resources management [19].

The government policy should put priority for coastal community to participate in coastal management based on the adat system. Panglima Laot, as an adat institution in Aceh which is related to the rights to manage the sea resources in Aceh has very important role to support the government program in managing its ecological space [17]. The success of managing this adat ecological space will determine the role of the Panglima Laot in preserving sustainable fisheries in Aceh.

\section{Adat Laot And Panglima Laot}

In terms of the adat ecological space, there are two very important aspects that needed to be studied. First, the regulatory aspect of the state law. In Aceh, following the peace talks between Indonesia and the Aceh Mardeka Movement in Helsinki on 15 August 2005 in Helsinki, a new law was established namely the Republic of Indonesia's Law 11/2006 on the Government of Aceh, hereinafter referred to as the Undang Undang Pemerintah Aceh (UUPA) which also acknowledges the existence of the local wisdom of Panglima Laot (article 98 and article 165 UUPA), in the utilization of natural resources, should not dominate one another, in this case between economy, social, ecology, and cultural interests. To impliment the local wisdom which is stated in new law of Government of Aceh, the Acehnese parliament has passed the Qanun (by-laws) relating to customs and customs development, namely Qanun Number 9 Year 2008 and Qanun Number 10 Year 2008. In addition, the provisions about local wisdom can actually be traced through Qanun Aceh Number 7 Year 2010 on fisheries and marine affairs.

Second, from the position of sociological legal arrangement, there seems to be an attraction of vested interest in the management of coastal resources. This vested interest of coastal resource management based on local wisdom had often contrary to the overlapping regulation of the State law. This condition gives rise to the question of whether the position of local wisdom in the State law is only meant to accommodate global consensus, which the involvement of the communities in saving the environment as has been discussed at the Earth Summit in Rio de Janeiro in 1992, resulting in the Rio Declaration, in Principle 22 which states that "... indigenous peoples and their communities, and other local communities have an important role in environmental stewardship and development because of their knowledge and traditional norms". 
Globally, it is already understood that local wisdom cannot be ignored. The concept of local wisdom is synonymous with local knowledge, indigenous knowledge, traditional ecological knowledge, and rural knowledge. According to Gadgil, Berkes, and Folke, local knowledge is a cumulative knowledge and hereditary belief of the community in their relationship with the environment [10]. In Indonesia, a concept was developed by Keraf, who regarded local wisdom as forming patterns of everyday behaviour towards fellow human beings, nature, and the Unseen. Keraf calls the practice of managing environmental resources as positioning the environment within a sacred domain [3]. This view of the environment is the special characteristics of people living with local wisdom. beside, they have owned what has been termed as the rights of the ulayat laot [22]. In today's modern era, local wisdom valued like Panglima Laot can be implemented for development program policy [7].

In Aceh, especially after the tsunami, the adaptation process has started to be fiercely rekindled [8, 32]. Practically, the inclusion of the Panglima Laot institution as a guardian of local wisdom continues to be challenged, especially when it involves protecting marine resources from the use of destructive fishing gear $[23,24]$.

As stated above, the Panglima Laot's existence is closely related to the rights of the ulayat laot's. The term 'the rights of the ulayat laot' may be defined as a special power under the customary law for the management of the marine territory. The use of the term 'laot' (sea) in the phrase 'the rights of the ulayat laot', is to distinguish it from the "the right of the ulayat darat (land tenure)". In fact, there are differences between ulayat darat and ulayat laot. Ulayat darat is more easily determined compared to ulayat laot. The ulayat laot are communal in nature, to regulate, to control, and exercise for the common interest; although it does not mean closing the opportunities for outsiders to access to the sea. The rules relating to the management of rights of the ulayat laot are mostly constructed in an unwritten form, sourced from local wisdom. The term 'ulayat' in Indonesian legal system, has long been known in the Indonesian history of law [28]. However, in reality of the centralization of law in Indonesia has been narrowed the position and the states perspective on ulayat right. The transfer of right is often done in a manner inconsistent with the adat law. The transfer of rights that does not heed ulayat rights will be opposed by the community. The transfers that take place will cause a clash to a bloody conflict between the licence holder and the public $[29,25]$

In the current context, the rights of the ulayat themselves are in accordance with the concept related to the rights to manage, in which the state delegates the authority of state control over right to manage to the regions (province and district) and the indigenous people. However, Law no. 5 of 1960 on the Agrarian laws determines a number of conditions of right to manage of ulayat for indigenous people namely; (1) as long as the fact remains; (2) it should be which in accordance with national and state interests, based on national unity; (3) should not conflict with other laws and (4) other higher regulations. This requirement are very difficult to achieve by the adat community. This requirement is considered by the adat law community as a form of doubt and suspicion of the state against them [5].

The above four coditions also apply to Aceh. All laws relating to land, sea and resources are always associated with the national agrarian law. In such context the rights of ulayat laot should also be seen in connection with the Agrarian Law. Panglima Laot is an institution related to the ulayat laot right.

According to T. Rayeuk, there are a number of principal signs in the institution of Panglima Laot, namely [30]:

(a) Panglima Laot is the head of the institution of adat laot (Customary Law) chosen by the pawang (sea master) as the fisherman's representative of the territory. Panglima Laot must come from the circle of pawang and understands the adat laot, because Panglima Laot beside as the head of adat laot, he also the chairman of the customary court to execute and funish the culprit in fishing comunity

(b) The Panglima Laot is an institution who control and implement the adat laot. It is not a political institution and must be distinguished from other coastal professional organization such as the Indonesian Fishermen Association (HNSI) as well as other institutions conducting activities within the coastal communities.

(c) The responsibility of Panglima Laot to make peace in fishing community (hukom peujroh), to protect and maintain the customary law of the sea, to mobilize fishermen to carry out social custom in case of accident or disaster, to lead traditional ceremonies, and to preserve and care for the sustainability of the environment within its jurisdiction.

(d) The institution of Panglima Laot exists only in coastal areas and waters where fishermen engage in fishing activities. Thus, this institution does not exist in areas where there is no coastal area. 
(e) The object of the customary law of the sea is the fishermen; both individuals as well as groups engaged in fishing activities those living in the coastal areas. Essentially, the object of adat laot covers personal or groups who inhabit the land with no regards for their professional background.

(f) The territory of Adat laot is formed not on the basis of a particular administrative territory but has been formed in such a way that it is permanent because it is determined by its geographic state. The territory of Panglima Laot had been determined since the existence of the institution of adat laot. Thus the territorial boundaries of the adat laot only follow the geographical conditions of the sea, and they cannot be changed for administrative purposes and the like.

(g) The history of the Institute of Panglima Laot is only known at the lhok under Mukim teritory. (level, which differs in its position with the tiered Syahbandar (harbour master) institution.

Based on the description above, what is considered the territory of the Adat laot should be separated from the concept of administrative boundary. Therefore, the division and regulation based on the customary spaces are very clear and strict. Even by following the concept of the customary institution's existence, the customary laws and institutions that regulate the use of each space in the customary territorial space are clear.

Under such a scheme, the area under the Adat laot is a part of the customary ulayat rights of the communities that should be separated from the general administrative area. According to T. Rayeuk, the Adat laot areas are not all coastal and marine areas. This region is only part of the coastal areas where fishermen pull the Aceh traditional nets (pukat Aceh), and most of the waters are where traditional fishermen fish [30, 26].

Based on the Adat, the territory under the jurisdiction of the adat laot, can be seen through the concept of the coastal space distribution covering the estuary (kuala), teupin or sea shore), leuen pukat or area for net repairing to the open sea. In addition to that, the territory enacted by the customary law of the sea (hak ulayat laot) is wider than the territory of the customary law of the sea itself. The Adat laot's territory is related to the community's customary rights (hak ulayat laot) of the area. But, the territory of the Adat laot also applies to fishermen who come from certain areas who are experiencing customary disputes about fishing. According to the custom, disputes that can be resolved are not limited to civil disputes, but also criminal disputes, but the cause of the dispute is the activity of fishermen in catching fish, not others. However, nowadays, moving from the state law arrangements, disputes that can be resolved are limited to civil disputes, especially those relating to fishing activities.

The wider scope of the conflict cannot be separated from the customary law's perspective on fishing activities. Customary law sees the process of fishing and the territory of the Adat laot as the unity of ecosystems that cannot be separated. Since certain criminal behaviour during that time will have implications for the Adat laot, it should be resolved by customary law. For example, in the case of fishermen who used certain fishing methods in a particular fishing area that did not practise such methods and in a territory ruled by the Adat laot [30,26].

In general, in the division of space, the Panglima Laot Institute has the following tasks: (a) maintaining and supervising the provisions of customary law and the customs of the sea; (b) coordinating and supervising any fishing effort at sea; (c) Resolving disputes between the fishermen or their groups; (d) maintaining and administering the traditional ceremonies involving the sea; (e) maintaining trees on the beach that should not be felled as the fish will move away from the sea (needs to be adapted to local conditions and situations); (f) acting as a liaison between the fishermen and the government and also between one Panglima Laot with another Panglima Laot; (g) improving the living standards of fishermen/coastal communities.

The sea customs, related to the coastal ecological customs, are bound by three main restrictions, namely: (a) prohibition of cutting/destructing trees on the coast of the sea such as arun/spruce, pandanus, ketapang, mangrove and other trees that grow on the beach; (B) prohibition of bombing, poisoning, inducing anesthesia, electrifying, removing coral reefs, and other materials that could damage the environment and other plants or animals in that habitat; (C) prohibition of fishing other marine animals and plants protected by the laws and regulations.

The above prohibition also directly relates to two aspects of the marine environmental problems: (1) the regulation about the use of fishing gear and the prevention of using fishing gear which damages the environment and the restriction on the distance between a particular catching area to certain fish habitat; (2) prohibiting the use of unfriendly fishing gear, removing waste, disposing of vessel repair materials, and disposing of oil into the coastal areas [33, 34].

The three restrictions are interrelated. The prohibition of cutting or damaging trees will largely determine the natural shoreline so various sediments can be retained. Sand-induced wind movement is also hindered by the trees. In addition 
to the customary maintenance of the environment, there are social customs in the operational life of the fisherman that broadly determine two things: first, at the time of the destruction of the ship/boat or other fishing device at sea, they give a sign by raising a flag as a sign of distress. Boats that see the signal will immediately come close to provide assistance. Secondly, if any fishermen happen to drown at sea, the entire boats will find the corpse for at least one full day and if there is a boat that comes across any corpses in the sea, the boat is obliged to take and bring the corpse back to the mainland.

Basically, the two customs describe the unification of the social circle of the coastal communities and the "land" community. In the "land" society, every occurrence of a disaster, must be solved or assisted as a group. If a disaster is related to a person who died, then the fardhu kifayah (Islamic religious communal responsibility) must first be fulfilled before the society can go about their daily activity.

In addition, there are customs pertaining to drifting goods. In this case, every item (boat, ship etc.) that drifted in the sea and found by a fisherman must be handed over to the local Panglima Laot for further stewardship. Included in the category of various drifting goods are items that can be ascertained not owned by the coastal communities in the area; the discovery must be submitted through the Panglima Laot.

\section{Panglima Laot: From The Past For The Future}

Panglima Laot has been known since the time of the Pasai Kingdom, even Marco Polo who visited Pasai in 1292 and settled there for 6 months, was always accompanied by a Panglima Laot in order to get a good catch [2]. The Panglima Laot institution continued to live and flourish during the period of Aceh's Kingdom from the 17th Century to the present [6]. According to Wilson and Linkie, despite existing for more than seven centuries, Panglima Laot is still relevant as a source of local wisdom that still manifests itself in Aceh in the field of marine management [31].

In the span of seven centuries, it appears that a number of dynamics had occurred in the Institution of Panglima Laot. An important dynamic as mentioned by Anthony Reid is that in the early period of the Kingdom, Panglima Laot's main duty was to collect taxes from the ships that stop at a port and second, mobilised the people especially fishermen to fight in a war. At the time of the last Sultan of Aceh, Sultan Muhammad Daudsyah (1878-1939), Teuku Umar Johan Hero was appointed as the Panglima Laot (amir ul-bahr) of the Kingdom of Aceh in 1886. On behalf of the Panglima Laot, he collected a tax of $\$ 0.25$ per pikul $(62.5 \mathrm{~kg})$ for the Sultan who was based in Keumala [1].

In addition, in the last Kanun Syarak Kingdom of Aceh issued in 1270 H (1854 AD), Panglima Laot was subjected to the Hukum Laksamana (Admiral's Law). According to Snouck Hurgronje, Panglima Laot was no longer an extension of the Sultan's authority but governed the customs, marine practices, and related social life in the region [4].

According to the authors, the changes recorded by Hurgronje were very political at the time. As a colonial advisor, such an opinion was considered ambiguous and intended to bypass the influence of Panglima Laot in mobilising the war against the colonial power. By simply sticking to the customs, marine matters and social life, Panglima Laot no longer strived to be an important force mobilising the power of war.

Van Volleh Hoven as the founder of the Leiden School of Leiden said the position of Panglima Laot is also structurally very important. According to Hoven, Panglima Laot officially regulated in the state, which governed the fishing areas on the basis of the Sultan's letter. The mention of the Sultan's letter affirmed the fact that Panglima Laot too had the authority to rule over its territory on the coast. This was confirmed by Hoesein Djajadiningrat who mentioned Lhok's Panglima Laot as the head of a lhok or kuala (estuary) or bay, who headed a number of trawls [26].

The generations of customary researchers agreed with Teuku Djuned findings. He mentioned that the problem of Panglima Laot's power had already taken place in the community of the Adat laot, either before or after being regulated by the legislation. It is important to note that the issue of the sea custom is something that is already engrained in the fishing communities in Aceh [21]. 
The above description illustrates the spirit of the local people in Aceh in sustainably utilising marine resources. This is particularly true with regards to local wisdom; there were also rules and customary courts, as well as having a territory with clear resources.

In addition, the Institutes' functionaries also undertook a revitalization effort for the young generation in Aceh. Referring to the Decision of the Meeting of Panglima Laot in Aceh 23-25, 1992 in Langsa (East Aceh), it was revealed that the effort to write, in terms of the effort of the revitalization of the customary law of the sea in Aceh, is a conservation effort that started since 1990. In particular, in cases involving the ethics of various fishing methods, Panglima Laot had been implementing deliberations to formulate since January 14, 1972 in Kabupaten, Aceh Besar District.

The effort to create a written customary rules has been made by the Aceh Special District Office since 1978, through the Supplementary Regulation of Sea Customary Law/ Procedures for Fishing with Fishing/Free Fishing in the Free Sea between Trawler Boats and Boats using Paddles/Aceh Trawls and Conclusion of the Deliberation of Panglima Laot from the whole of Aceh Besar and Banda Aceh.

The situation is important to be examined so that in the future, the Adat laots, as a form of local wisdom, can be as an implementation framework for the management of marine resources in Aceh. This offer is not excessive, considering the local reality in Aceh is very close to the life of the community. It may be said that the pattern is already engrained in society.

It is this wealth that is offered for the future of Aceh. The pattern of local wisdom in the form of the Adat laot of the sea can be used as a model in sustainable ocean management in Aceh. The Adat laot is carried out by Panglima Laot. Panglima Laot and the Adat laot in Aceh, in addition to making arrangements about fishing, also regulate the prohibition of the destruction of the marine environment, and the existence of prohibition in environmental destruction, on superstition related to the sea on certain days, have implications for the management of the ecosystem $[16]$.

Moving on from the consensus of the Rio Declaration, the realisation about the importance of local wisdom is in harmony with the global will that promotes the concept of sustainable development at the beginning of the 21 st. The concept of sustainability has become a global consensus. A total of 177 countries that met for the Rio Declaration had to apply this in various provisions in the country.

The general concept that can be traced from the Rio de Janeiro Declaration is about the capacity of the current situation to not diminish the interests of future generations. One of the reasons that initiated this concept was the concern of the state leadership about the natural degradation of the earth; this was regarded as the failure of the Stockholm Declaration, in particular on the condition of the global environment which had declined in quality after the agreement. Nevertheless, the concept also had produced some successes, among others in the field of normative and institutionalisation of the international world. Along with environmental sustainability, the concept of local wisdom was also discussed. These two issues are related to each other. Environmental sustainability is the ultimate goal, while local wisdom is a pattern for its accomplishment.

\section{Harmony Of Marine Resource}

In Indonesia, Keraf is one of the intelectuals offering ethics in dealing with the environment and the utilization of resources. One of the principles offered is how the humans should strive to be in harmony with nature. Here, nature doses not always have to be seen as wealth to satisfy human needs. Departing from such concept, the potential of marine resources, is not only seen as a tool to improve material welfare but also maintain the balance of the ecosystems that will contribute to the balance of life in the universe.

This case is determined from the beginning in Law no. 11 of 2006; the authority to manage marine resources should be carried out by taking into account the principles of sustainable development and environmental conservation. Another emphasis is in conjunction with the maintenance of customary law in Aceh. 
There are two important points mentioned above, namely the positioning of Adat laot and the management of the sea by considering the principle of sustainable development. The core of the Adat laot which deals with environmental issues, does not escape the context of sustainable development. The above rules and restrictions illustrate the goals of sustainable development [13]. By understanding the purpose of sustainability, the great potential of marine resources does not create a policy that exceedingly benefits the current generation. The utilisation process must coexist with the environmentally friendly concept, non-destructive patterns, and always pay attention to future generations.

Aceh has a great potential, with 119 islands and a coastline of 2,666.27 km. The water area reaches $295,370 \mathrm{~km} 2$. Its potential resources can reach up 1.8 million tons per year. Seen from the perspective of utilisation, material welfare should be a concern. In fact, until now, the poverty rate of the coastal communities is very high, with a figure of over $20 \%$. However, it is not that way, the problem does not stop at the level of utilisation, but rather it extends to how the treasure of the sea can become part of human life.

Poverty is still considered a factor that causes environmental damage. The solution to the problem of poverty is also one of the targets that need to be globally resolved. Hence, it is a key role of human, individuals and institutions, to determine the fate and future of marine resources. This is partly because the management of the sea should encourage the preservation of the quality, diversity and availability of sufficient resources for the present and future generations, in the context of the fulfilment of food needs for the people, poverty reduction and sustainable development.

\section{Conclusion}

The potential of the sea utilised in such a manner in order to achieve sustainability must be protected not only by strict regulation from destructive behaviour but also in favour of the local wisdom of Adat laot and Panglima Laot. Local people view environmental sustainability as something that integrates nature with values.

\section{References}

1. A. Reid. Asal Mula Konflik Aceh (Jakarta, Yayasan Obor, 2005).

2. A. Ricci, The Travels of Marco Polo the Venetian, London: Routledge, 1994.

3. A. S. Keraf. Etika Lingkungan (Kompas, Jakarta, 2010)

4. A. S. Usman. Nilai Sastera Ketatanegaraan dan UU dalam Kanun Syarak Kerajaan Aceh dan Bustanul Salatin, (Penerbit UKM, Bangi, 2005).

5. A. Sodiki, Politik Hukum Agraria (Jakarta, Penerbit Konstitusi Press, 2013).

6. Adrianto L, Amin MA, Solihin A, Hartoto DI. Konstruksi Lokal Pengelolaan Sumberdaya Perikanan di Indonesia (Bogor, IPB Press, 2011).

7. Busilacchi, Russ GR, Williams JA, Sutton SG, Begg GA. The Role of Subsistence Fishing in the Hybrid Economy of an Indigenous Community. Journal of Marine Policy 37 (2013).

8. Chaliluddin, A. Purbayanto, D. R. Monintja, M. Imron, J. Santoso. Institution of Panglima Laot in Supporting Sustainable Capture Fisheries Based on Local Wisdom in Aceh Jaya District. International Journal of Sciences: Basic and Applied Research, 16, 2 (2014).

9. D. S. Adhuri, Saat Sebuah Desa Dibakar Menjadi Abu: Hak Ulayat Laut dan Konflik Antar Kelompok di Pulau Kei Besar, Antropologi Indonesia, 57 (1998).

10. Gadgil, M., F. Berkes, C. Folke. Indigenous Knowledge for Biodiversity Conservation. Ambio 22 (1993).

11. Hardin, G. Tragedy of the Commons, Science 162 (1968).

12. M. A. Abdullah, T. M. Mansur, S. Tripa, Kearifan Lokal di Laut Aceh (Banda Aceh, Panglima Laot, 2010).

13. M. A. Abdullah, S. Tripa, T. M. Mansur. Selama Kearifan adalah Kekayaan (Jakarta, Panglima Laot dan Yayasan Kehati, 2006).

14. Markus T. Towards Sustainable Fisheries Subsidies: Entering A New Round of Reform Under the Common Fisheries Policy. Journal of Marine Policy, 34 (2010).

15. M. H. Daudy, Kedaulatan Laut Berbasis Sumberdaya Lokal: Perspektif Hak Asasi Manusia, Kanun Jurnal Ilmu Hukum, 63 (2014). 
16. M. H. Nya' Pha, "Panglima Laot: Peranannya dalam Lembaga Adat Laot”, Makalah Duek Pakat Panglima Laot se-Aceh di Sabang, 19-20 March 2001.

17. Ostrom, A General Framework for Analyzing Sustainability of Social-Ecological Systems. Science, 325 (2009).

18. Peterson, N., B. Rigsby (ed.) Customary Marine Tenure in Australia (Australia, University of Sydney, 1998).

19. Pita C, Pierce GJ, Theodossiou I. Stakeholders Participation in the Fisheries Management Decision-Making Process: Fishers' Perceptions of Participation. Journal of Marine Policy 34 (2010).

20. Ruddle K., Akimich, T. (eds), Maritime Institutions in the Western Pacific (Osaka, National Museum of Etnology, 1984).

21. S. M. Syaref,. Leuen Pukat dan Panglima Laot dalam Kehidupan Nelayan di Aceh (Jakarta, Yayasan Rumpun Bambu dan CSSP, 2003).

22. S. W. Ananingsih. The Developments of Customary Marine Rights: A Case Study in Kei Islands, Southeast Maluku Regency. Journal of Wetlands Environmental Management, 2, 2 (2014).

23. Sulaiman. Pembangunan Hukum Perikanan Berkelanjutan Berbasis Kearifan Lokal. Kanun Jurnal Ilmu Hukum, 16, 3 (2014).

24. Sulaiman. Kearifan Tradisional dalam Pengelolaan Sumber Daya Perikanan di Aceh pada Era Otonomi Khusus. Jurnal Dinamika Hukum 11, 2 (2011).

25. Sulaiman, S. Bahri, M. A. Abdullah. Sisi Lain Ulayat Laut: Perspektif Hukum Pengelolaan Pesisir Berbasis Hukum Adat Laut (Banda Aceh, Bandar, 2017).

26. T. Djuned, "Membedah Adat dan Hukom Masyarakat Aceh", dalam L. Munir (Ed.), Menuju Revitalisasi Hukom dan Adat Aceh (Banda Aceh, YRBI dan CSSP, 2003).

27. T. Djuned, "Kedudukan Panglima Laot dalam Hukum Positif di Indonesia", Makalah Duek Pakat Panglima Laot se-Aceh di Sabang, 19-20 Maret 2001.

28. T. I. Elhakimy. "Tata Cara Primair Peralihan Hak Atas Tanah Ulayat Menurut Hukum Adat di Aceh", dalam L. Munir (Ed.). Menuju Revitalisasi Hukom dan Adat Aceh (Banda Aceh,: YRBI, 2003).

29. T. I. Elhakimy, Beberapa Segi Hukum Adat tentang Tanah Pedesaan Aceh, Laporan Penelitian (Banda Aceh, Lembaga Penelitian Universitas Syiah Kuala, 1981).

30. T. Rayeuk, "Panglima Laot dan Wilayah Hukum Adat Lautnya", dalam L. Munir (Ed.), Menuju Revitalisasi Hukom dan Adat Aceh (Banda Aceh, Yayasan Rumpun Bambu, 2003).

31. Wilson, C., \& Linkie, M. The Panglima Laot of Aceh: A Case Study in Large-Scale Community-Based Marine Management after the 2004 Indian Ocean Tsunami. Oryx, 46, 4 (2012).

32. Y. Rinaldi, D. Suhendra, C. Desyana, R. Setiyaningrum. The Document of Analysis on Policies the Management of Fishery and Marine Resources of Nanggroe Aceh Darussalam Province, (Banda Aceh, WWF-Indonesia, Aceh Program Office, 2007).

33. Z. Imran, M. Yamao, "Konstruksi Peran Panglima Laot Lhok Menuju Tata Kelola Kawasan Konservasi Perairan Daerah Berbasis Sosial-Ekologi Sistem”, dalam Sulaiman (Ed.), Aceh, Kebudayaan Tepi Laut dan Pembangunan (Banda Aceh: Pusat Studi Hukom Adat Laot dan Kebijakan Perikanan Universitas Syiah Kuala, 2014).

34. Z. Imran, M. Yamao. Toward Strengthening Social Resilience: A Case Study on Recovery of Capture Fisheries after Asia's Tsunami in Aceh, Indonesia, World Academy of Science, Engineering and Technology International Journal of Environmental, Chemical, Ecological, Geological and Geophysical Engineering, 6, 9 (2012). 